\title{
COMPARISON OF PERFORMANCES BETWEEN THREE COMMERCIAL ELISA KITS FOR DETECTION OF ANTIBODIES AGAINST PORCINE REPRODUCTIVE AND RESPIRATORY SYNDROME VIRUS (PRRSV) IN SWINE SERA SAMPLES
}

\section{Zorana Zurovac Sapundžić1*, Milan Ninković1, Bojan Milovanović ${ }^{1}$, Dimitrije Glišić ${ }^{1}$, Vesna Milićević ${ }^{1}$, Branislav Kureljušić ${ }^{1}$ \\ ${ }^{1}$ Institute of Veterinary Medicine of Serbia, Belgrade, Republic of Serbia}

\section{ABSTRACT}

Porcine Reproductive and Respiratory Syndrome (PRRS) is one of the most economically important diseases in pigs, worldwide. In the USA alone, the total cost to the swine industry has been estimated at $\$ 664$ million per year. Therefore, the continuous and reliable monitoring of the PRRS status of a pig herd is required in order to prevent and reduce the costs caused by this infection. Nowadays, commonly used methods for laboratory diagnosis of PRRS infection are serological (ELISA) and molecular (PCR) ones. This study aims to assess the sensitivity and specificity of three different commercially available ELISA kits for detection of antibodies against PRRSV (IDEXX PRRS X3 Ab Test (IDEXX, USA), INgezim PRRS Universal (Ingenasa, Spain), and Pigtype PRRSV Ab (Qiagen, Germany)) using 91 blood serum samples collected from pigs in Serbia. Our study showed a certain level of differences in specificity and sensitivity between three commercially available ELISA kits. However, IDEXX ELISA proved to be a more reliable kit for detecting antibodies against PRRSV with sensitivity of $97.4 \%$ and specificity of $98.1 \%$, compared to INgezim and Qiagen kits specificity of $92.5 \%$ and $83 \%$, respectively, and sensitivity of $94.7 \%$ for both kits. In order to achieve maximal reliability of the obtained results, ELISA diagnostic protocol for laboratory diagnosis of PRRS infection should be complemented with additional tests such as PCR and virus neutralization test.

Keywords: PRRS, ELISA, sensitivity, specificity

${ }^{1 *}$ Corresponding author: zorana991@hotmail.com 


\section{UPOREĐIVANJE KARAKTERISTIKA IZMEĐU TRI KOMERCIJALNA ELISA KITA ZA DETEKCIJU ANTITELA PROTIV VIRUSA REPRODUKTIVNOG I RESPIRATORNOG SINDROMA SVINjA (PRRS) U UZORCIMA SVINjSKOG SERUMA}

Zorana Zurovac Sapundžić ${ }^{*}$, Milan Ninković1, Bojan Milovanović ${ }^{1}$, Dimitirije Glišić ${ }^{1}$, Vesna Milićević ${ }^{1}$, Branislav Kureljušsić ${ }^{1}$

${ }^{1}$ Naučni institut za veterinarstvo Srbije, Beograd, Republika Srbija

\section{Kratak sadržaj}

Reproduktivni i respiratorni sindrom svinja (PRRS) predstavlja jednu od ekonomski najznačajnijih bolesti u svinjarskoj industriji. Samo u SADu, ukupni troškovi procenjeni su na 664 miliona dolara godišnje. Kontinuirani i pouzdani nadzor PRRS statusa stada svinja je neophodan kako bi se smanjili troškovi prouzrokovani ovom infekcijom. Metode za dijagnostiku PRRS infekcije koje su najčešće u upotrebi danas su serološke (ELISA) i molekularne (RT-PCR). Ova studija je imala za cilj da ispita osetljivost i specifičnost tri različita komercijalno dostupna ELISA kita za serološku dijagnostiku PRRS-a (IDEXX PRRS X3 Ab Test (IDEXX, USA), INgezim PRRS Universal (Ingenasa, Spain), Pigtype PRRSV Ab (Qiagen, Germany)) koristeći 91 uzorak krvnog seruma sakupljenih od svinja u Srbiji. Rezultati ovog ispitivanja pokazali su da postoje izvesne razlike u izračunatim vrednostima specifičnosti i osetljivosti između 3 komercijalno dostupna ELISA kita. Ipak, IDEXX ELISA kit se pokazao kao najpouzdaniji kit za otkrivanje antitela PRRS-a, sa osetljivošću od $97,4 \%$ i specifičnošću od $98,1 \%$, u odnosu na INgezim i Qiagen kitove sa specifičnošću od 92,5\% i 83\%, redom, i osetljivošću od $94,7 \%$ za oba kita. Na osnovu dobijenih rezultata ispitivanja može se zaključiti da je u cilju precizne i pouzdane dijagnostike infekcije svinja izazvane virusom PRRS-a pored ELISA metode neophodno koristiti i druge laboratorijske metode kao što su RT-PCR i test virus naturalizacije.

Ključne reči: PRRS, ELISA, osetljivost, specifičnost 


\section{INTRODUCTION}

Porcine reproductive and respiratory syndrome (PRRS) is a contagious viral infection and one of the most common infectious diseases of swine globally, responsible for significant economic losses worldwide. The infection was first recognized in the USA in 1987, while the first cases in Serbia occurred in 2001, after illegal import of boar semen (Petrović et al., 2011).

The infection is caused by a single stranded RNA virus which belongs to the Arteriviridae family and the Arterivirus genus. The virus is biologically, antigenically and genetically heterogenic (Meng, 2000). Currently, PRRS virus is divided into two genotypes: PRRS-1 and PRRS-2 (ICTV - International Committee on Taxonomy of Viruses, 2018). Both genotypes are globally spread and enzootic in many countries. PRRSV-1 predominates in Europe while PRRSV-2 is most prevalent in Americas and Asia (Brar et al., 2015; Balka et al., 2018).

PRRS affects all categories of pigs. Clinical signs of PRRS vary greatly, from respiratory symptoms to reproductive failure in breeding herds, such as premature parturitions, late abortions and farrowing of stillborn and non-viable piglets. Clinical signs of PRRS are not characteristic and the course of PRRS infection can be subclinical, enabling the persistence of infection for a longer period in the herd until diagnosed, causing significant economic losses. In adult pigs, seroconversion may be the only indication that infection with PRRSV has occurred (Bojkovski et al., 2012). All of the above mentioned indicates that extensive surveillance programs are necessary for control of the infection in order to minimize losses caused by PRRS, as well as to improve animal welfare. Disease control nowadays often involves vaccination (Savić et al., 2018). The laboratory diagnosis of PRRS infection is sometimes very complex, due to significant antigenic diversity of field isolates (Milićević et al., 2020).

Most commonly used methods for detection of PRRSV are polymerase chain reaction (PCR) and enzyme-linked immunosorbent assay (ELISA). There are several commercial ELISA kits, usually used as a cost-effective method for detection of antibodies against PRRSV.

One of the most cited kits is IDEXX PRRS X3 Ab Test (IDEXX, Westbrook, USA) (Zimmerman et al., 2006) which stands out with great performances such as high sensitivity and specificity, easy protocol and reproducibility (Ferrin et al., 2004), though the occurrence of false-positive reactions is noted at a rate of 0.5-2.0\% (Zimmerman et al., 2006). ELISA results are sometimes indefinite and require additional tests (Antunes et al., 2015).

The aim of this study was to compare diagnostic sensitivity and specificity of three commercial PRRSV ELISA kits performed on 91 pig blood serum 
samples in order to determine the optimal tool for characterization of herd immunity.

\section{MATERIAL AND METHODS}

A total of 91 pig blood serum samples were used to evaluate the performances of three commercially available ELISA kits. For this purpose, serum samples were selected from the serum bank of the Institute of Veterinary Medicine of Serbia, collected during 2018 and 2019. Serum samples were collected individually from pigs located on different farms in Serbia with unknown PRRSV status and were brought to the Institute of Veterinary Medicine of Serbia for diagnostic purposes. Serum samples represent heterogeneous group of pigs, referring to different age of animals originating from different farms. All the samples were centrifuged prior to testing and were stored at the temperature of $-80^{\circ} \mathrm{C}$.

All the samples were analyzed using three different, commercially available indirect ELISAs: INgezim PRRS Universal (Ingenasa, Madrid, Spain) - in the following text referred to as INgezim, IDEXX PRRS X3 Ab test - in the following text referred to as IDEXX, pigtype ${ }^{\otimes}$ PRRSV Ab (QIAGEN, Leipzig, Germany) - referred to as Qiagen in the following text. All ELISAs detect antibodies to both PRRSV genotypes. The assays were performed with no modifications, according to the manufacturers' recommendations. In all three ELISAs, (S/P) cut-off value of positive samples is set at 0.4 . The optical density (OD) was measured by the ELISA reader (Multiscan, Labsystem). As the true PRRS infection status of the sampled animals was unknown, the diagnostic sensitivity and specificity of the three ELISAs were assessed based on the comparison of the proportion of the samples that reacted positively i.e. negatively. The samples that reacted positively in at least two applied kits were considered as positive, i.e. negative samples were marked as negative when at least two applied kits showed a negative result. False positive and false negative samples were regarded as samples that on one of the performed tests reacted ly i.e. negatively, while other two performed tests showed negative i.e. positive result, respectively. Sensitivity and specificity values for all three ELISAs were calculated according to the following formula (sensitivity $=$ number of true positives / number of true positives + number of false negative, specificity $=$ number of true negatives / number of true negatives + number of false positives).

The statistical evaluation was carried out using Chi Square test, with statistical significance at the level of $\mathrm{P}<0.05$. 


\section{RESULTS}

The results obtained from three commercially available indirect ELISAs for the detection of PRRSV antibodies are given in Table 1.

Table 1. Results obtained from three commercial ELISAs for the detection of antibodies against PRRSV

\begin{tabular}{|c|c|c|c|c|c|}
\hline ELISA & Positive & Negative & $\begin{array}{c}\text { False } \\
\text { positive }\end{array}$ & $\begin{array}{c}\text { False } \\
\text { negative }\end{array}$ & TOTAL \\
\hline & No. \% & No. \% & No. \% & No. \% & \\
\hline INgezim & $36 \quad 39.6$ & $\begin{array}{ll}49 \quad 53.8\end{array}$ & $4 \quad 4.4$ & $2 \quad 2.2$ & 91 \\
\hline IDEXX & $37 \quad 40.7$ & $52 \quad 57.1$ & $\begin{array}{ll}1 & 1.1\end{array}$ & $1 \quad 1.1$ & 91 \\
\hline Qiagen & $36 \quad 39.6$ & $44 \quad 48.3$ & $\begin{array}{ll}9 & 9.9\end{array}$ & $2 \quad 2.2$ & 91 \\
\hline
\end{tabular}

In total, the results obtained by INgezim revealed $4.4 \%$ of false positive samples, the ones by IDEXX $1.1 \%$ and those by Qiagen $9.9 \%$ of false positive samples. INgezim, IDEXX and Qiagen ELISAs detected 2.2\%, 1.1\% and 2.2\% of false negative samples, respectively.

Sensitivity and specificity values for all three ELISAs are given in Table 2.

Table 2. Sensitivity and specificity of applied ELISA kits for detection of antibodies against PRRSV

\begin{tabular}{ccc}
\hline ELISA & Sensitivity (\%) & Specificity (\%) \\
\hline INgezim & 94.7 & 92.5 \\
IDEXX & 97.4 & 98.1 \\
Qiagen & 94.7 & 83 \\
\hline
\end{tabular}

The statistical evaluation using Chi Square test has shown no significant difference between performed kits $(\mathrm{P}>0.05)$.

\section{DISCUSSION}

The most commonly used method for PRRS diagnostic is ELISA. A large 
number of publications comparing sensitivity and specificity of commercially available kits have been published (Diaz et al., 2012; Gerber et al., 2014; Sattler et al., 2015). In the present study, the performances of three commercially available ELISAs were compared between each other using pig serum samples collected from the field. Our results have shown that IDEXX kit with sensitivity of $97.4 \%$ and specificity of $98.1 \%$ has higher sensitivity and specificity in comparison to other two ELISAs. This result is in agreement with results of the earlier studies that also indicated excellent performance of this kit (Biernacka et al., 2018). Gerber et al. (2014) stated that IDEXX kit has specificity of $100 \%$, which almost agrees with the manufacturer's declaration (99.9\%). In this study, the highest number of false positives was acquired with Qiagen (9 samples), while the number of false negative samples obtained with Qiagen and INgezim was the same (2 samples). Our results for specificity of INgezim kit (92.5\%) are in agreement with results obtained by Sipos et al. (2009) where this value was $92.3 \%$. However, the improved version of this kit, INgezim PRRS 2.0, showed a clear increase in specificity, which was at the level of 99\% (Sattler et al., 2014).

Sattler et al. (2015) have calculated that the specificity of Qiagen kit is $98.1 \%$, while our results showed that this value was at the point of $83 \%$. Although some authors state high sensitivity of INgezim and Qiagen kits (Sattler et al., 2015), in our research, sensitivity of these two tests were equal (94.7\%) and are not significantly lower than sensitivity of IDEXX kit (97.4\%). The same authors (Sattler et al., 2015) cited that IDEXX distinguishes itself with a particularly high specificity, while the INgezim and Qiagen ELISAs stand out with a high sensitivity. Regarding the results of other authors (Sattler et al., 2014), we have also demonstrated that IDEXX and INgezim ELISA kits are reliable for the anti-PRRSV antibodies detection. However, despite their reliability, sometimes the specificity of the kits has been challenged by unexpected false positive results (Seo et al., 2016).

Furthermore, the results obtained with Qiagen ELISA kit, regardless of its high sensitivity (94.7\%), but compromised with low specificity (83\%), should be interpreted with caution and confirmed by another method due to the high percentage of false positive results. This is of paramount importance when testing herds free from PRRS infection either to maintain or prove their freedom. All the above mentioned leads to the conclusion that the selection of test should depend on the goal that is expected to be achieved and specific purpose of use.

Another point that should be taken into account is that validation of all tests should be performed with blood sera samples of local animals before their use in practice. The samples used in our study represent samples collected from the field, obtained from animals with unknown PRRS status, unlike 
other researches that used the herds with well-known PRRS status - experimentally infected or vaccinated animals (Diaz et al., 2012; Sattler et al., 2014).

The differences in the obtained results between the three kits may originate from different viral antigens used in ELISA kits, method of its preparation, the heterogeneity of local virus strains circulating in our country, etc. Furthermore, a relatively small sample size can be the reason for the obtained results and non-significant differences in performances of the tested kits. Our results are in agreement with reviewed publications and they show a good accordance between PRRSV ELISAs in general. Taking into account the heterogeneity of recently isolated PRRSV strains in different European countries, the definition of an adequate gold standard may be difficult (Karniychuk and Nauwynck, 2014). Regardless of the choice of applied ELISA kit for detection of antibodies against PRRSV infection, all assays should be complemented with virus neutralization test, that is internationally regarded as gold standard for final identification of PRRSV antibody positive individuals, or in any case with RTPCR for detection of virus presence.

\section{CONCLUSION}

Our study showed a certain level of differences in specificity and sensitivity between three commercially available ELISA kits. However, IDEXX ELISA proved to be highly sensitive and highly specific. PCR diagnosis or virus neutralization test should complement ELISA diagnostic protocol to ensure the maximal reliability of obtained results.

In any case, the choice of an applied test should be in accordance with specific situation and purposes specified in the beginning.

\section{Authors' contribution}

ZZS and MN drafted the manuscript. VM designed the study and carried out laboratory tests together with ZZS and MN; BM and DG performed statistical analysis; BK coordinated the work and revised the manuscript critically together with VM and prepared the final draft of the manuscript.

\section{Competing interest}

Authors declared no conflict of interests regarding the present paper. 


\section{REFERENCES}

1. Antunes A.C.L., Halasa T., Lauritsen K.T., Kristensen C.S., Larsen L.E., Toft N. 2015. Spatial analysis and temporal trends of porcine reproductive and respiratory syndrome in Denmark from 2007 to 2010 based on laboratory submission data. BMC Vet. Res. 11, 1-11. doi: 10.1186/s12917015-0617-0.

2. Balka G., Podgórska K., Brar M., Bálint Á., Cadar D., Celer V., Dénes L., Dirbakova Z., Jędryczko A., Márton L., Novosel D., Petrovic T., Sirakov I., Szalay D., Toplak I., Leung F.C.-C., Stadejek T. 2018. Genetic diversity of PRRSV 1 in Central Eastern Europe in 1994-2014: origin and evolution of the virus in the region. Sci. Rep. 17, 8, 7811. doi: 10.1038/s41598-01826036-w.

3. Biernacka K., Podgorska K., Tyszka A., Stadejek T. 2018. Comparison of six commercial ELISAs for the detection of antibodies against porcine reproductive and respiratory syndrome virus (PRRSV) in field serum samples. Res.Vet. Sci. 121, pp. 40-45. doi: 10.1016/j.rvsc.2018.10.005.

4. Bojkovski J., Dobrosavljević I., Delić N., Savić B., Rogožarski D., Petrujkić T. 2012. Porcine reproductive and respiratory syndrome (PRRS). Contemporary agriculture, 61, 1-2, 61-67.

5. Brar M.S., Shi M., Murtaugh M.P., Leung F.C. 2015. Evolutionary diversification of type 2 porcine reproductive and respiratory syndrome virus. J. Gen. Virol. 96, 1570-1580. doi: 10.1099/vir.0.000104.

6. Díaz I., Venteo Á., Rebollo B., Martín-Valls G.E., Simon-Grifé M., Sanz A., Mateu E. 2012. Comparison of two commercial enzyme- linked immunosorbent assays for the diagnosis of porcine reproductive and respiratory syndrome virus infection. J. Vet. Diagn. Investig. 24, 344-348. doi: $10.1177 / 1040638711435804$.

7. Ferrin N.H., Fang Y., Johnson C.R., Murtaugh M.P., Polson D.D., Torremorell M., Gramer M.L. Nelson E.A. 2004. Validation of a blocking enzymelinked immunosorbent assay for detection of antibodies against porcine reproductive and respiratory syndrome virus. Clin. Diagn. Lab. Immunol.11, 503-514. doi: 10.1128/CDLI.11.3.503-514.2004.

8. Gerber P.F., Gimenez-Lirola L.G., Halbur P.G., Zhou L., Meng X.J., Oppriessnig T. 2014. Comparison of commercial enzyme-linked immunosorbent assays and fluorescent microbead immunoassays for detection of antibodies against porcine reproductive and respiratory syndrome virus in boars. J. Virol. Meth. 197, 63-66. doi: 10.1016/j.jviromet.2013.12.001. 
9. Karniychuk U.U., Nauwynck H.J. 2014. Performance of assays for testing antibodies against porcine reproductive and respiratory syndrome virus in sera collected from swine farms in a region with an extreme virus heterogeneity. Acta Veterinaria, 64, 1, 44-51. doi: 10.2478/acve-2014-0005.

10. Meng X.J. 2000. Heterogenicity of porcine reproductive and respiratory syndrome virus: implication for current vaccine efficacy and future vaccine development. Vet. Microbiol. 74, 309-329. doi: 10.1016/S03781135(00)00196-6

11. Milićević V., Kureljušić B., Veljović Lj., Valčić M., Stević N., Savić B., Radojičić S. 2020. The performance of Seven Molecular methods for the Detection of PRRSV. Acta Veterinaria, 70, 1, 51-57. doi: 10.2478/acve-20200003.

12. Petrović T., Milićević V., Prodanov-Radulov J., Lupulović D., Maksimović Zorić J., Ivetić V., Došen R., Lazić S. 2011. PRRS infection in Serbia - current knowledge and problems. In: Proceeding and short contents, The First International Epizootiology Days, 6-9. April 2011, Sijarinska banja, Lebane, 30-31.

13. Sattler T., Wodak E., Revilla-Fernandez S. Schmoll F. 2014. Comparison of different commercial ELISAs for detection of antibodies against porcine respiratory and reproductive syndrome virus in serum. BMC Vet. Res. 10, 300. doi: 10.1186/s12917-014-0300-x.

14. Sattler T., Pikalo J., Wodak E., Schmoll F. 2015. Performance of ELISAs for detection of antibodies against porcine respiratory and reproductive syndrome virus in serum of pigs after PRRSV type 2 live vaccination and challenge. Porcine Health Manag. 1, 19. doi: 10.1186/s40813-015-0015-9.

15. Savić B., Radanović O., Kureljušić B., Milićević V., Stevančević O., Zdravković N. 2018. Reproductive and respiratory syndrome of pigs (PRRSV): Structure, evolution and antigens of PRRS virus (PRRSV), immunity and vaccine against PRRSV infection. In: Proceedings of the $16^{\text {th }}$ Conference „Health care, selection and reproductive of pigs” Srebrno jezero, 31. Maj 02. Jun 2018, 34-52.

16. Seo B.-J., Kim H., Cho H.-S., Park B.-Y., Kim W.-L. 2016. Evaluation of two commercial PRRSV antibody ELISA kits with samples of known status and singleton reactors. J. Vet. Med. Sci, 78, 1, 133-138, 10.1292/jvms.15-0126.

17. Sipos W., Lang C., Minani A., Fischer L., Ritzmann M., Schmoll F. 2009. Comparison of two commercial ELISA systems for the detection of PRRSV-specific antibodies with a gold standard ELISA. Wien Tierärztl Mschr - Vet Med Austria, 96, 28-33. 
18. Zimmerman J., Benfield D.A., Murtaugh M.P., Osorio F., Stevenson G.W., Torremorell M. 2006. Porcine reproductive and respiratory syndrome virus (Porcine arterivirus). In: Diseases of swine. Eds. Straw B.E., Zimmerman J.J., D’Allaire E.S., Taylor D.J., 9th ed., Blackwell Publishing, Ames, Iowa, USA, p. 387-417.

19. International Committee on Taxonomy of Viruses, available at: https:// talk.ictvonline.org/taxonomy/

Received: 27.08.2020.

Accepted: 22.11.2020. 